\title{
Nursing in Times of Neoliberal Change: An Ethnographic Study of Nurses' Experiences of Work Intensification
}

\section{Rebecca Selberg}

Department of Gender Studies, Lund University, Sweden ${ }^{1}$

\begin{abstract}
Through an ethnographic study of nurses' experiences of work intensification, this article shows how nurses respond to and act upon neoliberal transformations of work. The article identifies and explores those transformations considered by the informants, nurses working in public sector hospital wards, as central to changing conditions of work and experiences of work intensifications. It further analyzes nurses' responses toward these transformations and locates these responses within a particular form of femininity evolving from rationalities of care, nurses' conditions within the organization, and classed and gendered experiences of care work. The article illustrates that in times of neoliberal change and public sector resource depletion, nurses respond to women's traditional caring responsibilities as well as to professional commitments and cover for the organization. Maintaining the level of frontline service is contingent on increased exploitation and performance control of ward nurses, and their ability and willingness to sacrifice their own time and health for the sake of their patients. The article argues that in the case of ward nurses in the Swedish public sector, work intensification is a multilayered process propelled by three intersecting forces: austerity ideology linked to the neoliberal transformation of the welfare state and public sector retrenchment; explicit care rationalities impelled by aspirations of the nursing profession to establish, render visible, and expand the nursing field both in relation to the medical profession and in relation to so-called unskilled care work performed by assistant nurses and auxiliaries; and the progressive aspect of New Public Management, which challenges the power and authority of the professions and contributes to strengthening the positions of clients and patients.
\end{abstract}

\section{KEY WORDS}

Care work / emotional labor / gender, nursing / Swedish healthcare / work intensification

\section{Introduction}

he aim of this article is to analyze how nurses respond to and act upon neoliberal transformations of work. The article identifies and explores those transformations considered by my informants, nurses working in public sector hospital wards, as central to changing conditions of work and experiences of work intensifications. It further analyzes nurses' responses toward these transformations and locates these responses within a particular form of femininity evolving from rationalities of care, the working conditions within the organization, and experiences of care work, studied here through a class and gender informed analysis of care work and work intensifications. By using ethnographic data to explore issues of work intensification in the public sector, the

\footnotetext{
${ }^{1}$ E-mail: rebecca.selberg@genus.lu.se
} 
article contributes to a deepened understanding of effects of welfare state transformation on care workers, as well as continuities and change in processes of exploitation and worker adaptation involved in the everyday production of welfare services.

The article is organized as follows. First, I will describe changes in the Swedish healthcare sector, focusing on New Public Management (NPM). In the succeeding section I outline the analytical frame of the article, focusing on gendered aspects of the conditions of labor processes in public sector care work. I then go on to describe the methodology. The remaining part of the article is an analysis based on an empirical study of ward nurses and their experiences of changing working conditions in a Swedish hospital.

\section{New millennium healthcare in Sweden}

Since the late 1980s, Swedish healthcare has faced radical changes. The neoliberal transformation of the welfare state and implementation of NPM doctrine have deeply affected the working conditions of employees in the public sector (Aili \& Nilsson 2007, Anell 2012, Berg Jansson 2010, Blomgren 1999, Blomgren \& Sahlin 2007, Gustafsson 2000, Hasselbladh et al. 2008, Whitehead et al. 1997). Research shows that in the wake of welfare state retrenchment and public sector resource depletion, healthcare professionals both in Sweden and internationally report increased pressure at work (c.f. Bejerot et al. 2011, Eliasson 2011, Gardulf et al. 2008, Hasselhorn et al. 2003, Hertting et al. 2005, Wilkins 2007, Willis 2005). Work intensification has been illustrated to decrease job satisfaction and increase stress among nurses (Zeytinoglu et al. 2007). Willis (2005, p. 256) argues that in the case of nurses, labor speed-ups are "bolstered by the impact of work intensification on other groups working alongside nurses, be they doctors, allied health professionals, or cleaners." Nurses in Sweden report difficulties in coping with intensified labor processes and decreased resources, causing them among other things to feel stressed and anxious, to burn out, and to have breakdowns at work (Glasberg et al. 2007, Stockholm County 1999, SWEA 2012). Thus, within this highly feminized segment of the Swedish labor market, employees have been facing increasingly complex labor processes, growing workloads, and drastic organizational changes in terms of new models of management and stricter day-to-day economic realities for over two decades.

During the 1980s and 1990s, the neoliberal transformation of the welfare state intersected with the "international management revolution" that called for radical changes in the public sector with the aim to reduce costs, implement pseudo-market mechanisms, and improve services (Montin 2012, p. 2). These changes within public sector organizations, which took place in most Western countries during the 1990s, are commonly referred to as NPM. NPM not only involves changing management techniques and accounting models but also implies "a more fundamental shift in norms and beliefs concerning the public sector and its relation to the private sector" (Blomgren 1999, p. xi), as public sector organizations model their governance on private companies. The principal argument is that profit in private business stimulates productivity through "the owner's effort to discipline the labor force and the ability of the entrepreneur to identify new solutions" (Gustafsson 2000, p. 101). Because no easily identifiable profit can be produced through the work performed in public organizations, NPM emphasizes cost reduction (Hasselbladh et al. 2008, p. 60). Thus, key in NPM is the introduction of quasi-markets 
and contracting-out, as well as stressing the role of active management, which thereby challenges trade unions and public sector professional groups such as the medical profession (Agevall \& Jonnergård 2010). The emphasis on management extends to the audit process and includes a focus on performance measurement (van Thiel \& Leeuw 2002). Decentralization and cost control are linked processes as the responsibility of cutting costs is moved down within the organizations, leaving low-level managers to handle savings measures (Hasselbladh et al. 2008, p. 59).

Increased use of financial control mechanisms represent the most radical change in Swedish public sector management since the 1980s, according to Hasselbladh et al. (ibid.), who point out that while the state has not regulated practices in this area, the so-called budget balance-demand has enforced stricter local priorities, which has created a continuous chase for expenses. Further, decisions that used to be handled by political mandate have moved down in the organization, and "have thus often come to appear as value neutral, technical measures" (ibid.). In their summary of the implementation of NPM regimes in the Swedish public sector, Hasselbladh et al. capture what others have called "the double-edged sword" or the hybrid character of NPM as it prescribes "both more autonomy and more central control at the same time" (Christensen \& Laegreid 2007, p. 8).

In Sweden, processes of professionalization accompanied NPM reform as it was implemented in varying forms during the 1990s. Consequently, nursing aides and assistant nurses lost their jobs in great numbers: assistant nurse positions decreased by $37 \%$ between 1993 and 2001. At the same time, the number of physicians and registered nurses increased by $9 \%$ and $5 \%$, respectively (Hertting et al. 2005), marking a change toward increased professional dominance of care work processes.

NPM has micro as well as macro effects (Ferlie et al. 1996). Blomgren (1999) analyzed through three empirical studies the effects of NPM on the nursing profession and nurses' working conditions in Sweden. She argues that the implications of new management regimes were divergent in relation to nurses and created differences within the nursing collective. Her data showed that in trying to cut costs and increase efficiency, hospital clinics chose not to prioritize time-consuming practices related to nursing. Thus, for ward nurses working the shopfloor, time became an issue in such a way that patient care suffered. "This outcome reflects the fact that economic logic helped to reproduce the subordinate position of nursing in relation to medicine," Blomgren (1999, p. xv) notes. On the other hand, new managerial regimes reinforced the positions of nurse managers whose responsibilities expanded as clinics were consigned with delineated economic obligations. Further, quality assurance programs contributed to strengthen nurses' jurisdiction, as it provided nurses with an abstract field of knowledge-a central feature in the system of professions and thus a positive development in nurses' professional aspirations (see also Abbott 1988). The trade union identified that new managerial regimes necessitated clarification of nurses' role in the healthcare organization, and emphasis was put on rendering nursing visible through stressing the importance of documentation (see also Agevall \& Jonnergård 2010, p. 124).

\section{Analytic framework}

In order to understand nurses' collective as well as individual responses to such changes, there is need for a conceptualization of the dynamics of collective identities and power 
structures at play within work organizations and occupations. Research on work identity has pointed out the interdependent relationship between workers' individual identities and work structures, but has also showed that the self is socially and culturally constructed and that "certain elements of a person's identity will always be collectively imposed" (Kirpal 2004). During the last thirty years, scholars have further identified that gender, like class and race/ethnicity, is at the core of organizations and a key feature of structures and processes of work (Acker 1990, 2006). Employees' identities and their possibilities to maintain, resist, or transform conditions of work are thus shaped through the actual labor process they are involved in, the gendered power relations that frame them, and the positions and experiences that they occupy and make outside of paid work. Thus, identities are not stabilized as people enter paid work, but are rather "open, negotiable, shifting and ambiguous" (McDowell 2009, p. 54), and they are, as Brah \& Phoenix (2004, p. 77) point out, not "objects but processes constituted in and through power relations." Material and ideological conditions and the relations of power that workers' are drawn into through the workplaces shape the ability and space available to respond to and act upon neoliberal transformations of work. These processes are gendered. Specifically, occupations and jobs are associated with and shaped through assumptions of varying forms of masculinities and femininities; for instance, in Salzinger's (2000) study on maquiladoras, femininity was linked to docility and efficiency, but also to desirability, as the panopticonlike factory located male supervisors as voyeurs and workers as sexual objects. Other women workers may be called on because they are associated rather with mothering, the moral duties of the welfare state, and hence notions of respectability.

Nursing, which has been conceptualized as "an element of the sexual division of labor, an occupation blending a particular version of femininity with the technical requirements of the job" (Connell 1987, p. 181), is one such example. Bessant (1992, p. 159) has argued that the historical link between middle-class women and nursing has been central in regulating nurses' behaviors and professional identities. Becoming a "good nurse" has historically been closely linked to being a "good woman." Learning how to be a good nurse has involved "reinforcing the proper habits and attitudes, a sense of responsibility, attention to detail and obedience to the rules and regulations of the hospital and to superiors." Nurses' collective work identities are tied up with the project of normative femininity, which is associated with notions of respectability and responsibility. I conceptualize normative femininity as a form of femininity organized around the moral authority that is culturally and ideologically linked to motherhood and the upbringing of the nation (Roberts 1997, Skeggs 1997).

The emphasis on responsibility can take on different forms within the professional project of an occupation such as nursing (another example would be teaching; see Widerberg 2005). Research indicates (Nylinder 2011, p. 670), for example, that nurses are better at maintaining budgets and more careful to consider and respect economic ramifications than doctors are, who tend to emphasize autonomy and medical considerations over demands of balanced budgets and "bureaucratic principles determined by the county councils" (ibid.). The responsibility implicated in the gendered professional project of nurses can be argued to be not only directed toward the patients but also to the healthcare organization and its bureaucratic principles which nurses take pride in maintaining (for an ethnographic exploration of this, see Selberg 2012). A principal area of responsibility for nurses historically has also been to bring order to the hospital, in terms of cleanliness, emotional and physical boundaries toward patients, 
and organizational principles (Bohm 1961, Chiarella 2002). With NPM, nurses have been given renewed responsibilities for maintaining the organization and its budgetary and administrative ramifications. However, as research has illustrated, it has also challenged the pride nurses take in caring for patients by combining empowerment and patient-in-center-ideology with work intensifications and resource depletion (Foster \& Hoggett, 1999). In a qualitative cross-country comparison of work identities of nurses in Estonia, France, Germany, and the UK, Kirpal (2004, p. 297) concluded that nurses "experienced increased pressure and time constraints, leading to a conflict between providing patient-oriented care and rationalization," and that it was "almost entirely up to the individual nurse to find a balance between caring and efficiency demands." In another qualitative study, Cooke (2006, p. 231f) found that NHS nurses' workloads had "increased enormously" as patients went through the system "sicker and quicker" and nurses took on more routine, low-status work. Structural conflicts emerged between nurses and managers wherein nurses "felt torn between their responsibilities to their patients and the demands of managers" (ibid.). There is, then, a growing body of research showing that nurses across the West are struggling to maneuver on the one hand professional aspirations and on the other hand organizational restructuring, which is pushing back resources and means to perform care work in ways that correspond and live up to nursing ideals. These ideals are also historically and ideologically gendered and bound to notions of "good," altruistic, respectable middle-class women.

Notions of gendered work identity have been identified as central aspects in processes of constructing consent and practicing dissent in paid work (Burawoy 1979, Ong 1987). Research has illustrated that notions of masculinity and femininity can be used in processes of interpellation, wherein management names workers in order to construct idealized subjects. The workers internalize these ideals and conform to or recognize themselves in this naming, embodying managerial assumptions or stereotypes (Burawoy 1979, McDowell 2009). However, in interactive service work, this process takes on a dual form, as workers conform to and are named by not only the management but also by clients (Williams 2006).

The concept of interpellation is useful in understanding continuity and change in constructing ideal workers through the regulation of appropriate forms of femininities (and masculinities) in workplaces. The analytical framework here is materialist understandings of the ways in which ideal worker constructs are gendered, linked to varying forms of femininities, and the ways in which they constrict and/or create space for workers to respond to transformations of work. The specific focus of this article is on changes related to experiences of work intensification. According to Burchell (2002), work intensification deals with the effort put into the job by employees. A common distinction here is between "extensive" and "intensive" efforts, the former referring to the time spent at work, which can be extended by working more hours, and the latter referring to physical as well as emotional or mental input (Green 2001).

What are the specificities of care work in this context? In her discussion on labor process change within care work, Cohen (2011, p. 190) argues that there are three main constraints on the possibilities for (re)organization in healthcare linked to the specificities of performing work on bodies. The first is based on the "rigidity in the ratio of workers to bodies-worked-upon," the second is related to the "requirement for co-presence and temporal unpredictability," and the third is based on the complex, unitary, responsive, and recalcitrant nature of bodies as a material of production. Cohen's examination of the 
challenges in organizing and reorganizing care work illustrates the complex labor processes in play on the shopfloor of a surgical ward. Care work is labor intensive, not easily subsumed under capitalist clock time, and centers on material that is inherently unpredictable. It is important, however, to emphasize the presence of a structured labor process in which workers produce the service of care. While public sector care work is different from the production of goods and services in the private market, it is increasingly performed in relation to pseudo-market mechanisms (ibid.). Labor process analysis brings attention to the ways in which the production of goods and services "shape (and are in turn shaped by) conflicts of interest between employers' perceived interests (for instance, increasing profits, saving costs, controlling or monitoring workers' input...) and by what workers define as theirs" (Wolkowitz 2006, p. 12). Because of the historical traditions of care work as feminine labor performed within the private realm and outside of monetary exchanges (England \& Folbre 1999), the labor process in healthcare ties in to unpaid work outside of employment relations. One of the most significant interventions in examining this relationship is the work of Waerness (1984), who illustrated that care work has a specific rationality to it that challenges the bureaucratic rationality of organizations. Rationality and emotionality in this sense are not opposing qualities (Astvik 2003, p. 7). The care rationality is an aspect of the gendered division of labor and correlates to norms in the private sphere, dictating that a person in need should always be cared for. But, as Cohen (2011, p. 190) points out, "work and employment in health and social care settings is played out on the same territory as other work in capitalism"-a territory marked by varying forms of conflict and constraint and "shaped by the imperative on capital to continually increase productivity and, to this end, engage in ongoing reorganisation and rationalisation of the labour process" (ibid.).

Consequently, care work is performed on territory that is gendered and tied to divisions of labor across the private/public divide, marked by conflict and constraint, shaped by capitalist logic, performed by both unskilled and professional workers with professional aspirations, and carried out within organizations whose current management regimes pose contradictory and divergent demands on the occupation claiming jurisdiction over care and its specific rationality. Nursing in itself is associated with normative forms of motherhood and linked to notions of respectability. This analytic framework links labor process analysis to work performed in spheres that traditionally has been constructed as outside of the economy (Nelson 1996) and expands the sociology of work by drawing attention to social relations and practices associated with reproductive labor (Wolkowitz 2006, p. 3). By locating my study within this analytic framework, I am able to illustrate continuity and change in paid care work by focusing on the organization of labor and the ways in which it is structured by hierarchies and divisions outside of the healthcare institution.

\section{Research methods}

The study is situated within the tradition of institutional ethnography, a method of inquiry rooted in feminist epistemology. By beginning in the standpoint of women, institutional ethnography aims to explore the ways in which people are connected into "extended social relations of ruling and economy and their intersections" (Smith 2005, p. 29). Institutional ethnography investigates practices, empirical linkages, and coordi- 
nated work processes in an effort to identify and change the social relations that create inequalities (DeVault \& McCoy 2006, p. 19). Interview data and observations are used to gain entry into the social organization of experience; how are participant's actions and talk conditioned (Campbell 2006, p. 95)? The analysis begins in experience and "returns to it, having explicated how the experience came to happen as it did" (Campbell 2006, p. 91). Experience is understood as a form of dialogue that is produced from a specific location in the world, and in this case, within the healthcare organization. The sociological significance of nurses experiencing and dealing with new demands on work and identity is what it can tell about ruling practices in today's labor market (Burawoy 1991, p. 281). While the analysis is based on data derived from a specific place and time, and a "specific set of actors and their experiences" (Campbell 2006, p. 105), a broader analytic interest is directed at the ways in which a neoliberal and globalized economy and related management technologies are enforced on, maneuvered, and enacted by workers in the public sector. It is the relations that organize these workers' experiences that can, in the words of Campbell (ibid.), "be demonstrated to be general."

This article builds on data collected during five years, between 2006 and 2011. During this time, I interviewed 15 nurses, 5 assistant nurses, 5 physicians, 3 physiotherapists, and 2 nurse managers; in this article, I will focus on the experiences of the nurses and exclude data collected among the other occupations. The semi-structured interviews lasted between 1 and 3 hours. All of the informants worked at hospitals within one County council. The interviews took place either at the respondent's workplace or in their home.

In addition to interviews, I conducted fieldwork at one of the hospitals in the County, here called City hospital. Initially, the workplace observations took place at different wards of the hospital, where I shadowed a nurse or an assistant nurse (and in one case a physiotherapist) for two half-shifts each (between 4 and 6 hours, a total of between 8 and 12 hours per ward). I visited the wards on different days and covered different shifts. Like Czarniawska (2011, p. 95), I find shadowing a fitting technique in work environments such as hospitals where work is not always spatially demarcated, but rather "on-the-move." I did observations in this manner in a pediatric ward, an emergency intake ward, a psychiatric ward, a surgical day clinic, a birth clinic, and two surgical wards. I then proceeded to do fieldwork for a more extensive period of time at one of the surgical wards, here called Ward 96, which treats mainly pre- and postoperative cancer patients. I spent a little more than 150 hours at this ward, excluding the times I went there to conduct planned interviews with nurses. I shadowed mainly nurses $(N=7)$ but also two assistant nurses and the nurse manager. I covered all shifts, including two full night shifts where I shadowed a nurse. During the observations at Ward 96, I conducted unstructured conversational interviews with nurses, physiotherapists, nurse managers, nursing students, a cleaner, an aid who mainly worked in the ward kitchen, as well as three doctors. I sat in on staff meetings, rounds, a nurse manager meeting for the surgical division of the hospital, as well as coffee breaks and lunches in the staff lounge. I was in contact with the nurse manager during the entire period of fieldwork and conducted a total of five unstructured interviews with her, in addition to the first planned interview I conducted before beginning the fieldwork. Toward the end of my fieldwork, I was invited to share my findings at the "staff education day," and I took notes of the nurses' responses to my analysis of the data collected at their workplace. ${ }^{1}$

Within institutional ethnography, texts are considered to be central to "how people's work is concerted" (Smith 2005, p. 212). In organizations, documents connect 
people into translocal social relations and produce stability and replicability (Smith 2005 , p. 228). Smith argues that by incorporating texts into ethnographic studies, it is "possible to expand exploration of institutional relations into higher levels of organization" (Smith 2005, p. 212). In addition to interviews and workplace observations, this study builds on textual analysis of financial documents from City hospital, along with documents and presentations produced during a restructuring project launched a few years before I commenced fieldwork. Starting from the standpoint of care workers, I attempted to relate their experiences and situated knowledge of intensified work processes to concretized reports of the local economy. By local economy, I refer to the economy of the hospital, the County, and the healthcare sector in Sweden. I studied four years of financial reports (2008-2011) including policy and funding recommendations and decisions from the County.

Thus the data of this study consist of documents related to the financial operations of City hospital, in addition to transcribed interviews and extensive field notes.

\section{Nursing in times of neoliberal change}

\section{The intensified labor process: background to the development at Ward 96}

Ward 96 was one of the specialized surgical wards at City hospital. It cared for patients predominantly diagnosed with cancer and was both "high tech" and "high touch" (Brush 2000, p. 162, McDowell 2009, p. 167) in the sense that patient treatment required technology-intensive care as well as hands-on help with hygiene, nutrition, and body mobility. For several years, management had prioritized recruiting registered nurses over assistant nurses, and the ward currently employed only a handful of assistants compared with two dozen nurses, covering four shifts and at least 22 patients. This meant a less strict division of labor between nurses and assistants than what I had observed at other wards. Sometimes, if Ward 96 was short an assistant nurse but was fully staffed on the nursing side, a registered nurse would "temp" as assistant. All of the nurses on the ward were female except for one male nurse who worked the night shift and a male assistant nurse who worked day shifts.

The ward had struggled with a high turnover of nurses and was generally considered to be a "tough" ward to work in because of its complex care program, but mostly because of its high workloads. Nurse Selma summed it up by stating that "it's too much now; ever since they closed the ward at the [nearby] hospital, it's been hell here." Selma, who was in her late 30s, had been working at the ward for ten years. In her quote, she was referring to a restructuring process set in motion a few years back, which changed the volume and quality of patient intake. Selma's boss, Katarina, who was in her early $50 \mathrm{~s}$ and used to be a nurse at the ward, explained what happened when the County hospital infrastructure changed in an effort to increase productivity:

Everything changed for us with that. What happened was, we got all major surgery and [a ward at a nearby hospital] got all minor surgery. We got all surgery where there is risk of complications. We fight to keep at least some planned operations here. The influx of emergency cases is much greater now. This means increased workloads because the patients we treat are a lot sicker and suffer from more complications due to the operations. 
The new hospital infrastructure was a political project aimed at shaping the county healthcare sector along three lines of production in order to provide both patients and staff with a "more cohesive" care chain. However, County representatives also explained the restructuring process by pointing to a mounting "discrepancy" between available resources and costs of care, i.e., the new care infrastructure was introduced in order to cut costs.

Management described the project as "not primarily" aimed at restructuring the organization, but rather to adjust the "ways we work together." What was actually being reorganized was the patient flow and type of care provided at specific hospitals. Before the project was launched, Ward 96 and a surgical ward at a nearby hospital performed matching operations covering the same, diverse groups of patients. After the reorganization, emergency and at-risk cases were directed to City hospital, while its corresponding ward at the other hospital handled all minor cases and most planned surgeries. This effectively increased the workload at City hospital and made work more unpredictable and complex.

The restructuring project fit into NMP strategies in its focus on cost reductions and increased productivity through teamwork solutions, its emphasis on organizational as well as employee flexibility, and the implementation of task separations and more active management strategies (Ferlie et al. 1996).

Financial reports from City hospital during this period mention increased pressure to produce care within stricter fiscal restraints. For example, in a report from the finance division at City hospital, top management explained the plans to effectuate a saving requirement prompted by the new County budget. The plan was for City hospital to let go of a couple of hundred people, mainly by not replacing personnel who would retire during the year; by effectively stopping wards to recruit new personnel; by increasing practices of out- and insourcing and benchmarking toward other hospitals; by reducing the time spent by medical staff on administration and make them spend "more time with patients"; by considering plans to "improve efficiency" in both psychiatric and somatic care; by even further restricting purchases of IT and telecom software and hardware, furniture, medical equipment, and technology; and by even further restricting personnel to attend courses and conferences.

In Ward 96, four nurses and two assistants were let go over a period of two years as a result of fiscal constraints. Further, there was no intake of temps when only one or two nurses or nurse assistants called in sick. There was one less nurse on night shift. The practice of taking in personnel from temp agencies on an hourly basis was severely restricted, which left management struggling over scheduling. The workload had grown, but the number of nurses and assistant nurses had not.

\section{An increasingly dense and unpredictable labor process}

In addition to growing workloads, medical developments, advancements in nursing techniques and ideology, and customer-oriented management principles meant work was becoming more complex. The shift in the way patients were treated and approached through notions of individualized care and customer orientation (Montin 2012, Radwin \& Alster 2002) meant the job was more dense and more unpredictable than before, partly because the bar was raised from within the professions, but also because patients 
were more knowledgeable and demanding. Janet remembered when she, an assistant, and an aide took care of 22 patients during nightshifts in the 70s, and she thought that would be "unthinkable" today:

10-15 years ago, if [the patients] had diabetes, heart failure and God knows what else, we wouldn't operate on them. Today we do. And you try to do much more for them today, so no wonder it's getting harder. And the patients know more, they demand more, as do their families. And we demand more of ourselves, because we learn how to treat them, with individualized care and everything, what they should drink and how they should move. It's more complicated today; you don't just go in and put in a catheter on a patient like you did before.

Cohen (2011, p. 198ff) gives several convincing examples indicating that under NPM austerity ideology, care is increasingly standardized. Standardization is desired, Cohen argues, because "it enables the predictable allocation of resources" and facilitates a more constant work pace (ibid.). What nurse Janet is pointing at, however, is that increased demands on individualized care, both from within the professions and from patients, has rendered some features of care work less standardized. When Janet began working as a ward nurse, most patients regardless of their status had bladder catheters inserted. The Fordist-type organization of care prioritized making bodies more "predictable materials of production" (Cohen 2011, p. 198) over decisions based on the individual patient's ability. Today, the priority instead is attaining mobility and maintaining agency of patients, as well as preventing infections (Wald et al. 2008)—which in turn is linked to an increased emphasis on high turnover rates (c.f. Läkartidningen 2008). As one internet page puts it, "a catheter is not a substitute for good nursing care" (About.com/Surgery). Thus, as the organization recognizes bodies' unpredictability while striving for continual cost reductions, nurses have to maneuver an increasingly complex labor process that both affirms nursing as a field and accelerates the pressure on nurses' time and skills. From Janet's point of view, there were several factors behind growing workloads and heightened temporal unpredictability-some of which were linked to advancements in medicine and nursing, and some that were linked to management developments.

NPM attempts to achieve increased quality through an emphasis on customer orientation, which challenges the autonomy of the professions while attempting to strengthen the positions of clients (Caspersen 2007, Hasselbladh et al. 2008, Nordgren 2007). As Du Gay \& Salaman (1992) have illustrated, customer orientation increases the pressure on workers to perform, as the responsibility to orientate production toward serving the client is delegated to the shopfloor. However, as Bejerot \& Astvik $(2009$, p. 6) note, power over resources remains centralized.

For the most part, I found that nurses considered the discourse of customer-oriented care a productive and positive aspect of nursing, although they resented being treated like "mere service workers" (the same has been identified among doctors, see Bejerot $\&$ Astvik 2009). Janet, like many of the interviewed nurses who had worked hospital floors since the 1960s or 1970s, defended these changes and viewed them as strengthening the nursing profession. "When you put the patient at the center and you view him [sic] as a customer, you somehow put care work-our work-at the center too, not just the 'cutting out the bad part' [through surgery]," nurse Kerstin said during a conversation at the ward. Nurse Josephine, however, pointed to the difficulties of living up to the ideal 
of patient-oriented care. The resources provided, according to Josephine, did not match the ambition set out by the County. Consequently, nurses on the shopfloor would experience a fracture between goals and means. She explained that because the ward was often understaffed, there was "no chance for us to think about the patient's perspective and all that":

There is so much we need to do ... it's about pushing through the tasks, do what absolutely needs to be done: see to that wound, bring that patient to X-ray, call those people.

In this section, I will explore one aspect of the discourse of customer orientation that affected nurses' work: the organizational emphasis on flexibility and accessibility. While nurses felt there was no practical way of living up to ideals of patient-in-center ideology, their work was organized partly to facilitate this. This organization of work reduced nurses' backstage spaces and limited their ability to sequence their work according to their own planning. For example, while it was close to impossible for a patient or kin to contact the surgeons of Ward 96 without making due appointments and going through proper channels (meaning phoning a clinic nurse who would screen callers), nurses were expected to be reachable as soon as they clocked in. The ward had no visiting hours or phone hours. Nurse Majken thought that one of the biggest stressors of her work was the constant interruption caused by visitors: "We used to have visiting hours and telephone hours. The visitors, they always want to talk to us. It's a good thing, but it's also what's making this job so difficult," she told me during a morning shift. Being constantly accessible to families dealing with sickness heightened the unpredictability of work, as nurses would more often have to deal with family members seeking them out in hallways to answer questions or give support. Demands on accessibility are delegated to the lower echelons of the organization and it is primarily up to nurses and assistant nurses to actually represent and provide access and time-flexible service to families.

The cost of this on care workers is heightened levels of stress. For instance, the process of returning to a chore after having been approached by a family member looking for support would often demand a kind of "refocusing" on the remaining chores. In these instants, between two tasks in a broken-down work process, nurses would often mention how tired or frustrated they felt, and sometimes they would admit to being afraid of making mistakes. When a worried family member had interrupted nurse Janet on her way to the medicine supply room, she had to pause and refocus when she finally came there, and as she reached for the top shelf and carefully read the label on two boxes, she told me:

Did you hear about the nurse who was indicted for giving the wrong medication? These boxes look almost the same but the potency differs. I tell myself: don't stress when you do this, I mean even if I'm interrupted again, read the label! It's my nightmare to get this wrong because I was interrupted -, to come back in and grab the stuff and then get it wrong, because you want to get on track with what you were doing.

Accordingly, increased accessibility means increasingly fractured work processes. Being interrupted causes stress for several reasons, one being the fear of making a harmful mistake in the course of trying to repatch a work sequence. I would especially like to draw attention to the devastating consequences errors might have on patients and on nurses 
themselves, a responsibility nurses are acutely aware of (see also McDowell 2009, p. 165). Ward nurses handle high-risk assignments such as administering medication under increasingly stressful conditions in which their attention is more and more divided on multiple tasks at once.

\section{The contradictory effects of increased demands on emotional labor}

Accessibility is linked to increased demands on emotional labor, the management of feelings that "requires one to induce or suppress feeling in order to sustain the outward countenance that produces the proper state of mind in others" (Hochschild 1983, p. 7). Emotional labor in care work has been recognized as just as draining as the physical aspects of work (James 1992, p. 500).

The discourse of "professional manners" was frequently negotiated by nurses in conversations on the pressures of work. One of the main problems of feeling tired identified by the nurses was the effort it took to "keep up a professional appearance." It was not primarily the technical aspects of work that would suffer in these situations, but the quality of the emotional labor performed. Danuta reflected on this by measuring her performance under stress:

Danuta approaches the medicine trolley in the hallway, where Lena is working on the lap-top. Danuta says: "Let me tell you. Lena is the best nurse here, because she is the kindest. Yes, she is, because she is never mad. I get mad. I try not to, but when people yell at me I explode. I don't want to be mean but I am, it comes from inside me." Lena responds: "Well, you have to get it out. I take long walks in the woods, that's how I get it out, I work through it and I get it out, so I can come here and be happy.”

The exchange illustrates some of the ways in which nurses negotiate and reproduce the historical link between nursing as a profession and embodiments of compassion, consequently maintaining the association between reproductive labor, mothering, and normative forms of femininity (England et al. 2002, Waerness 1984). What this excerpt also illustrates, however, is the time and effort that goes into emotional labor and the regulation of feeling rules and empathetic interactions. Lena's response indicates that the management of emotions extends beyond the workday and takes efforts outside of it, while Danuta's account illustrates that failure to sustain a compassionate demeanor calls for a discourse of self-examination and self-doubt.

Twigg et al. (2011, p. 176) point out that emotional labor "maps neatly on to the gendered occupational hierarchies of healthcare, with the privileged, predominantly male professions relegating the emotional work" to "those lower in the pecking order." This is not a new part of nursing, however. Already in the 1950s, ethnographic research showed that those working closest to patients were exposed to more emotional pressures than senior staff, for which the Fordist-type organization created a distance toward the patients in order to "contain and modify nurses' anxiety" (McDowell 2009, p. 165f). As McDowell (ibid., p. 166f) illustrates, it used to fall on auxiliaries and even hospital cleaners to perform emotional labor linked to intimate and/or emotionally loaded interactions with patients and kin. Doctors and senior nursing staff would have access to distancing mechanisms, both in terms of training and professional ethics and in terms of 
organizational resources or practices that would create a buffer between them and the patients. When hospitals employed large numbers of assistants and aides, nurses were removed from high-touch "basic bodywork" and instead performed more of "high-tech, skilled interventions" (Twigg 2000, p. 390, also quoted in McDowell 2009, p. 167). My data indicate that for the nurses at Ward 96, this relationship is being restructured. Professionalization and customer orientation have drawn registered nurses closer into the care of patients and their kin, and nurses' work is increasingly performed frontstage. It is nurses who are required to perform emotional labor that complies with notions of time-flexibility, because it is nurses who are given the responsibility to embody quality, accessibility, and service at the hospital. This is in line with earlier research on gender and emotional labor in the public sector. Employees "most likely to be required to provide emotional labor in an organization are women," and specifically in public organizations, "female public servants are expected and required to engage in emotion work to a greater degree than men" (Meier et al. 2006, p. 899). As Meier et al. point out by referring to the groundbreaking work of Hochschild (1983), earlier research has identified "both gender- and class-based association with on-the-job emotional labor expectations." There is both continuity and change in the demands on emotional labor in the public sector care setting: on the one hand, it is still women- and female-dominated public servant occupations who are expected to provide emotional labor, and it is women who experience work intensification pertaining to heightened demands on the extent of emotional labor. However, the class-based association is being altered as registered nurses, who historically have been removed from some of the intimate interactions with patients as such tasks were allocated to auxiliaries and who used to spend less time on the shopfloor (c.f. Lindgren 1992), face increasing demands on accessibility, flexibility, and expanding contents of work in the name of professionalization of healthcare.

I want to point out in relation to this that emotional labor on the part of nurses is not always associated with compassion. Nursing historically has also had a civilizing mission (Skeggs 1997, p. 42), rendering nurses a moral authority over patients. Nurses exert control of the care labor process as they manage, in various ways, the work of assistant nurses and auxiliaries. Research has illustrated the presence of conflicts among nurses and involving nurses who abuse younger generations of care workers (Rowe \& Sherlock 2005), who manifest racism against coworkers (Porter 1993) and patients (Mulinari 2010) and discriminate against certain groups of patients who are consequently put at risk (Robertsson et al 2005). Researchers have also pointed out that while nursing discourse emphasizes "caring," nursing practice has been shown to involve humiliation and abuse of patients (Jewkes et al. 1998). The relationship between nursing and exertion of power and violence is under-theorized (although see Holm 1995), but lies outside of the scope of this article. I will point out, however, that work intensification and increased pressure on employees are likely to heighten the risk of such behavior (as Rowe \& Sherlock 2005 indicate in relation to intra-professional harassment among nurses).

According to the nurses in my study, one of the major problems of dealing with increased demands on emotional labor was the fact that they received little formal training to perform it, and that they rarely had time to understand the issues from the point of view of the patients. One aspect of emotional labor in care work is the assumption that it comes naturally to women in care work. This is not assumed in the same way as within the private sector, as Hochschild's (1983) and Barry's (2007) studies on flight attendants 
illustrate. In private service business, employees are trained to deal with customers and their feelings for commercial purpose. The nurses felt that they actually lacked training to handle such situations, but more importantly, many felt there was little time to sort out what was bothering the patients or kin. Nurses also expressed that complaints from patients could be difficult to handle because they stemmed from failures of the healthcare organization that nurses had no influence over, such as anxiety caused by delays in treatment due to lack of oncologists or surgeons on staff, etc.

This was linked to the reduced ability to provide care as a gift (Bolton 2000). Being stressed out meant that it was difficult to provide more time-consuming emotional support to the patients, and failing in this regard would add to the general stress among the nurses who felt they performed subpar. As Bolton (ibid.) also noted in her study, nurses experienced growing workloads as a rejection of "creative altruism," which negatively affected their work pride and job satisfaction. Increased demands on emotional labor among nurses is a contradictory process whereby nurses experience stress both because of their increased time in direct contact with patients, leaving the labor process to be more unpredictable and emotionally draining and also because it actually takes time away from what is experienced and thought of as meaningful interactions with patients.

\section{Shopfloor outcomes: extensive and intensive efforts}

The nurses I interviewed experienced their working conditions at Ward 96 as high stress, high risk, but they also described the care provided as high quality. While many of them complained about not being able to provide the best possible care because of fiscal restraints, most nurses thought the ward delivered "for the most part good-enough, once in a while supreme" care, as one nurse put it. This meant nurses performed under stressful conditions, but mostly without compromising professional or personal standards of nursing. In trying to understand if and where compromises were being made in the processes of production, I talked to nurses about how they managed their workload, and focused my ethnographic gaze on trying to identify nurses' efforts to finish different tasks. I found that nurses employed two strategies in order to provide care they themselves were satisfied with: extensive and intensive efforts. Extensive efforts refer to the ways in which nurses prolonged their workday so as to be able to finish their tasks. Intensive efforts refer to the ways in which nurses instead chose to compromise their own time and their own needs so as to be able to finish their tasks. The context under which these efforts were made is central. Here is a quote from Josephine, in which she describes the challenges of managing multiple demands on nurses' skills and time:

What is tough is that patients who feel bad -, emotionally they can be in a poor state-and then the telephone is ringing, and everybody wants something from you, and you're supposed to be there for so many and for so much.

The first time I met Josephine, I was shadowing another nurse at Ward 96 who had just clocked in. I realized that when 45 minutes had passed into the night shift, Josephine from dayshift was still there. I asked her about this when I interviewed her a few months later and she told me that she could not leave and felt forced to work for free: 
I think the County is using us. They steal the time in the flex calendar. .... They steal our time and our money.... Sometimes [you stay late] because you wait for your turn to report [to the next shift]. So that's 20 minutes that will be signed up in your flex calendar. And then you can't use it, it's not approved or there is no time to take advantage of it, and then three times a year they take out everything over 25 hours [in the flex calendar] so it's gone. There is so much that goes on around the really heavy care work. And the patients are so much sicker since they closed down the other ward [at the nearby hospital]. So it just keeps adding up and you end up staying late, again.

The quote is extensive but I use to illustrate two things. Firstly, Josephine's experience is that staying late is not an autonomous decision. She "ends up" extending her workday because there is no way to finish the tasks within the allotted time frame. The tasks, however, must be finished. Second, she does this without being fully remunerated. It was up to Josephine's manager to make sure staff did not overuse the flexsystem, meaning there was a limit to how much flextime one could use. If nurses did not finish within the time frame on enough occasions, the flex-calendar would max out and the hours would be erased in the system. Josephine identified the high levels of exploitation involved as the employer expropriated her work without compensating her, but saw no way out of this relationship. Other nurses explained that they would stay late because "it's about helping each other" and "we are not dealing with machines here, our responsibility is to human beings; by that I mean the patients." Nurse Selma, quoted here, argued that nurses have a responsibility to human beings other than themselves and the organization they work for, a responsibility exceeding the employment relation between care worker and employer. Feminist research has linked this type of commitment to the gendered division of labor, which has maintained an ideological association between women's care labor with unpaid work in the private realm. This relation has shaped the conditions of professional care work, explaining its devaluation. For example, in their study on why care workers "generally experience a decline in wage when entering a care occupation," England et al. (2002, p. 468) argue that the ideological association between care work and mothering is part of the explanation:

While mothers are revered, there is a sense that they should provide care out of love, not for money. This is part of why they are revered! This notion may be extended to paid care work so that care workers are implicitly expected to prove their proper motivation by accepting a wage penalty. (England et al. 2002, p. 457)

In addition to the wage penalty, my data indicate that nurses face high levels of exploitation because the caring responsibility is assumed on their part regardless of whether they are actually paid in the full for the hours they contribute to the organization. Moreover, the nurses themselves are hesitant to compromise with the levels and quality of care. They too feel that they should provide care, and so they do, even for free. Beyond exploitation, there is a level of self-exploitation here. But I want to stress that notions of self-exploitation have been associated with nurses for a long time (Mackay 1989) and is part of a pervasive image and self-image of nurses as being "too good," not assertive enough (Davies 1995). I see this as an important aspect of the role of normative femininity in the maintenance of exploitation in care work. 
Nurses at Ward 96 further employed the strategy of intensive efforts to manage their workloads. The intensive efforts heightened my attention to the corporeality of care workers. I initially discovered the corporeal aspects of intensive efforts by talking to a fellow sociologist who had done fieldwork at a hospital in the early 1990s. I asked her when was the best time to jot down notes, and she told me: "You take out your notebook whenever the nurse you're shadowing goes to the restroom". I thought it was good advice and planned on following it, but discovered that the nurses I shadowed did not seem to visit restrooms, which from my perspective seemed like a nature-defying ability. I shared this experience at the ward "staff education day" and was met with laughter, as most nurses recognized how they failed to go to the toilet for entire shifts:

Majken: It's funny, because all we do here sometimes is checking up on the patients' urine: the amount, the color, does it look all right? You give them drinks and think about their fluids. Then you come home, and your urine is dark brown because a) you haven't been drinking all day except for some coffee, and b) you haven't been going to the restroom all day.

Paula: We say: 'Pee we do on nights and weekends, and the rest we save for holidays and special occasions'! [Laughter]

In Theodosius' (2008, p. 3) ethnographic study of a British surgical ward, nurses reported the same thing: “... you have no time to go to toilet. Yet maybe now when we are saying something like that, somebody can't believe that something like that can happen, but it happens," nurse Maria says in an interview with the author. Across borders, nurses regulate their bodies and the very same needs they monitor in their patients so as to be able to manage growing workloads.

One reason nurses at Ward 96 felt they did not have time to go to the restroom was the absence of workload slackening. Cohen (2011, p. 197) argues that the temporal contrariness of bodies makes it difficult to "distribute work evenly across the working day," meaning that care work (and other forms of work performed on live bodies) tends to contain work peaks but also baggy time. At Ward 96, there was hardly any baggy time during day- and evening shifts, and nurses kept a constant high pace in moving between tasks. One nurse explained that they would "always run" to fetch things, to do things quickly. "Of course," nurse Lena said, "we are always interrupted so we forget things and then you run some more." Some nurses tried to take advantage of the constant high pace by wearing special sneakers that were supposed to shape the figure during walks. It was a common strategy and an appreciated skill to be able to do several things at once.

While baggy time had been eliminated, management seemed to have identified a need to re-conceptualize the intensive efforts on the part of nurses. The nurses told me that management had said, "It's not about running fast, but running smart." This management catch phrase illustrates the ways in which performance management aimed at defusing the effects of high workloads by renaming the costs and consequences on the part of the nurses. Being told to "run smart" instead of "fast" shows some of the new ways in which care work is being managed in times of "austerity," "efficiency," and performance management, in which nurses are expected to keep a high pace while at the same time take responsibility for the costs and manifestation of making the impossible possible, i.e., finishing the tasks at hand without enough time being allotted and without being fully remunerated. 
Many nurses linked the capacity to do several things at once to femininity. A recurring comment on the high workloads and low salaries was versions of the statement "men could never do this job"/"men would never do this job." Men lacked the ability to juggle many things at once, and perhaps more importantly, they would never accept having to be forced to do "a thousand things at once, while being paid nothing," as nurse Kerstin explained to me. Her explanation as to how and why nurses managed their workloads thus referred to taken-for-granted expectations on women's and female care workers' efforts, and to stereotypical notions of women's inherent abilities to cater to people in need.

\section{Interpellation: constructing seamless nurses}

In her discussion on interactive service employment, McDowell (2009, p. 61) draws on the work of Goffman (1959) and Williams (2006) to argue that front-stage service workers have to conform to and handle both managerial imaginations of idealized embodiment of service work and desires and fantasies of clients. In this section, I will focus on low-level management's attempt at constructing ideal workers and increase productivity through pressuring nurses to perform seamlessly despite high levels of exhaustion among staff. The first quote illustrates the ambition from the ward manager to make the nurses perform seamlessly, that is, without naming or acting on feelings of exhaustion:

I'm going to actively -, with some means work on making them feel proud of what we do. Because it's like this: right now everybody's pretty exhausted. We have too many patients and nobody has the strength, and the nurses don't want to do it, and many start thinking about quitting and go somewhere else because it's a tough ward to work in. So I feel like I have to -, you know, they have to accept that it's hard and stay anyway.

The nurse manager at Ward 96 could not describe in concrete terms what she meant by "actively with some means" make the nurses feel proud, but the statement speaks to the efforts of management to re-conceptualize the working conditions and repress expressions of dissatisfaction. In interviews with management and with ward nurses, there was a strong emphasis on individual performance, and many nurses recognized management's attempts at unearthing ways to make them perform better, more seamlessly, without adding resources. I use the word seamless here to indicate management's emphasis on defusing expressions of discontent and resistance through a kind of interpellation. Interpellation refers to the ways in which employers construct stereotypical notions of idealised workers in different class positions. This calling or naming in the work place is in turn internalised by workers themselves so that they come to conform to or recognise themselves in the managerial naming (Batnitzky \& McDowell 2011, p. 186)

I encountered numerous examples of how talk about how to handle growing workloads was redirected so that both the problem and the solution were placed among the ward nurses on the shopfloor. Lena's insistence that she needed to "run smarter, not faster" was one such example. But there were formalized components, too. Nurse Selma identified how annual salary reviews were actually used to monitor and increase work output. Selma stated that she felt exploited because despite taking on extra responsibilities (such as being made responsible for updating and supervising 
fire-rescue protocol and material), there never seemed to be any room for discussing a pay raise. Discussions with management centered on her performance, never the other way around:

I'm worth more I think. I have many extra duties, responsibilities. I'm not compensated for that. We never have salary reviews, it's called 'development dialogue', and we only talk about how I can develop myself! We never talk about how I can be remunerated for taking on all these extra duties. And I'm a great nurse. I'm not lazy, I take care of my patients, and I give my heart and soul. I know everything there is to know about this place.

Management actively repressed expressions such as these. One nurse shared a story of how she was called in to the office of the nurse manager after having complained, in the nurse lounge, about the high workloads and feeling fatigued. The manager told the nurse that such behavior "created a bad environment" and "affected the other nurses negatively." The nurse started crying, and was thoroughly upset because she felt she couldn't "... go out and keep a professional appearance to the patients when my eyes were red and puffy." For that, the manager later apologized. Calling for positive thinking, and warning against the collective damages associated with "negative thinking," is a form of powerful social control in the workplace that has emerged in the neoliberal era (Ehrenreich 2009). Interviews with the nurse manager illustrated some of the ways in which shopfloor-level performance management focused on reinforcing attributes, approaches, and appearances that created the illusion of a seamless labor process and a workplace culture without conflicts: "positive behavior." Nurses shared stories of how management prioritized nurses who seemed (to management) unfazed by harsh working conditions and offered these nurses career paths outside of the ward, such as administrative clinic duties that were not as high touch, high pressure, and unpredictable as ward nursing.

The manager further underscored differences within the nurse collective, by representing younger nurses as a positive force within the workplace but also as a threat to older nurses who expressed dissatisfaction with the working conditions:

There are some older nurses here who are just -, they are not too easy to handle. They tend to whine a bit. But they better watch out now, because here comes all these younger nurses, great girls, happy, positive, straightforward, they get things done.

From the manager's perspective, then, younger nurses posed less of a challenge in terms of performance management, while older nurses represented a problem because they did not adapt seamlessly to the changing working conditions and management regimes.

The issue of age differences in relation to worker subjectivity and adaptation should be explored further. Do new generations of nurses more easily comply with and consent to neoliberal ruling mechanisms because their identities and subjectivities as workers have been shaped in relation to a neoliberal school system, higher education, labor market, and welfare ideology (Fleming \& Spicer 2003, p. 158)? Or is it more likely that the difference is related to time and linked to the process of growing weary from years of high workloads? These questions fall outside the scope of this article, but merit further examination. 


\section{Performing beyond the boundaries}

In her discussion on the rationality of caring, Waerness (1984, p. 199) notes that care workers she had observed in a study would "break official job-instructions" in order to perform work according to their competence of caring, which was derived from work in the private realm. Often, Waerness states, "they had to work for more hours than they were paid." It is interesting to note the continuity of high levels of exploitation in care work, as women across borders and decades have been subsidizing the Scandinavian public sectors by working for free. What I wanted to emphasize here, though, is the way Waerness frames the phenomenon of working more hours than contractually agreed. By working longer in order to care for their patients, the women observed in Waerness' study defied the boundaries set by the organization. Waerness wrote in a context in which public care was questioned as impersonal and overly rationalistic (a discourse that contributed to pave the way for NPM), and she framed the employees' actions as challenging the healthcare organization and thus portrayed it as a-albeit contradictory-form of worker resistance. I was surprised when I found that management at Ward 96 viewed nurses' unpaid overtime as a form of defiance as well. Staying late was represented not as a sign of dedication and good, thorough nursing, but rather of failing to keep up the pace and disrespecting the boundaries of labor. This is a quote from the manager at Ward 96:

They have this need to finish, to complete their tasks. Which really is impossible in this ward. But that is their goal, and that is what's making them feel stressed. They want more time; they want to do better for their patients. They work so hard for their patients, and then they stay late and do the final stuff like updating patient records or whatever. ... I think they could be more proactive. We could probably benefit from a more -, I guess continuous dialogue, I could tell them that 'This is not legitimate overtime, you should have understood hours before that this was going to happen', something like that.

Caring for others has been associated with essentialist notions of women's innate capabilities of affection (Davies 1995, p. 2). Under NPM regimes, care work is subsumed under demands on efficiency and fiscal restraints. As research has illustrated, nurses on the floor experience such demands as at-odds with the rationality of care (Blomgren 1999). The paradox in commodified caring is that it is "both highly valorized (as more than a job, as a vocation) and devalued and correspondingly poorly remunerated" (McDowell 2009 , p. 163). This paradox takes on a new shape under NPM regimes and welfare state retrenchment. Care work is still devalued and poorly remunerated, while at the same time care workers are required to produce more with fewer resources and with expanding demands on their individual performance. As care must be efficiently executed so as to keep the organization cost-effective, low-level management challenges notions of specific caring rationales and vocational allegiances among nurses. While performing beyond the boundaries may make a good nurse, it assumes resources and organizational conditions that are not available and risks slowing down the pace of work. However, performing beyond the boundaries compensates the organization and conceals the discrepancy that exists between means available and emphasis put on quality of production. In this sense, then, the notion of nursing as a calling is reproduced through individual acts of resisting new logics for providing care, and through the institutionalized expectation that nurses 
will perform beyond the boundaries. "Caring too much" provides a buffer between what the organization proffers in terms of resources and what patients receive in terms of service. A paradox of nursing in times of neoliberal change is that care workers are called on to perform professionally, while at the same time being called on to assume women's traditional caring responsibilities and, in essence, cover for the organization.

\section{The costs of work intensification}

In this section, I will describe some of the costs of labor speed-ups on the nurses. The most evident and dramatic effect of growing workloads was emotional breakdowns. Nurses would start crying from stress. I witnessed this on a few occasions, and like Foote Whyte (1948) in his interviews with crying waitresses, I used these instances as analytic entry points to understand what kind of situations in the labor process would have such an impact on nurses' feelings. Nurse Janet, who had worked in the ward for a very long time and thought of herself as a skilled nurse and calm person, explained to me about feeling overwhelmed:

[I cried] right before my vacation. ... It was stress. I couldn't manage. I take on too much responsibility. ... [I've seen other nurses] cry. More and more they cry. They are overwhelmed because they don't know how to prioritize. You always have to prioritize but sometimes it's impossible because everything is equally important. That's when it comes, the tears. The patients must be cared for.

Nurse Selma, who asked to be called "The Iron Nurse" in this study, explained that she too had experienced breaking down at work:

I cried last Tuesday, and this Thursday. I had to leave everything and go hide, to cry. I had a patient, she was so ill, and I really thought she would die. And then on top of that there was a patient who vomited all over the place and I had to take care of that and change her clothes and everything. Then another patient got ill and I thought that one was going to die too. So I called the doctor twice and he got irritated. Then he came up here and said: 'Well, just give some morphine'. So I broke down in front of him and started crying. He said: 'You can go now'. Then the boss came and said: 'Just cry it out, it's good for you'. And I said: 'I don't want to cry at work! It's not normal to cry at work!' Why do people cry at work? The midwives in the birth clinic cry sometimes because of the beauty in a new child being born. Here, why cry from despair.

Such emotionally draining experiences clearly affected life outside of work. Many nurses expressed that work seemed to take over their time and their bodies. Nurse Paula explained that she was usually too tired to see friends after work; nurse Selma explained that she could hardly imagine being able to form a family because she was always too tired after work. Many shared a fear of not lasting till retirement. "I'm hoping I win the lottery," one nurse said jokingly, because she felt certain she wouldn't be able to work as a nurse until the age of 45 . Nurses in their early 30s complained of back pain and considered career paths that would take them out of ward nursing. Many complained of feeling exhausted, emotionally and physically. Their experiences echoed the report 
issued by the Swedish Work Environment Authority (SWEA 2012) that concluded that nurses and assistant nurses suffer disproportionally from work-related illnesses and injuries, with $60 \%$ of the cases being linked to "social and organizational factors" such as high workloads and stress.

\section{Discussion: understanding work intensification among nurses}

While there has been mobilization around demands of recognition and redistribution, such as the strike in 2008 and the "24000-crona-protest" in the spring of 2012 when nursing students around the country attempted to raise entry-level salaries, nurses continue to face increasingly harsh working conditions and have yet to accomplish any major improvements through collective acts of resistance. Moreover, the ethnographic data in this study suggest that nurses on the floor have no means available to identify spaces and strategies to resist work intensification under neoliberal management regimes in ways that would challenge the organization without also posing a threat to their professional standards and status.

I argue that in the case of ward nurses working the floor of the Swedish public sector, work intensification is a multilayered process propelled by three intersecting forces. First: Work intensification is a result of austerity ideology linked to the neoliberal transformation of the welfare state and public sector resource depletion. Second: Work intensification is a result of explicit care rationalities impelled by aspirations of the nursing profession to establish, render visible, and expand the nursing field both in relation to the medical profession and in relation to so-called unskilled care work performed by assistant nurses and auxiliaries. Third: Work intensification is a result of the progressive aspect of NPM, which challenges the power and authority of the professions and contributes to strengthening the positions of clients and patients. The latter point is important because it illustrates the ambiguous power relation between nurses and patients, and the continually ambiguous position of nursing within the healthcare institution. On the one hand, the holistic and individualized care that the nursing profession attempts to construct as their jurisdiction works to reinforce both nursing as a field and the position of the patient. As Erlöv \& Petersson (1992, p. 185) argue, when holistic or individualized care (depending on how it is labeled) was introduced in Swedish healthcare by the end of the 1970s and beginning of the 1980s, "one had to look back to the days of Nightingale to find a corresponding attention directed at the care work performed by nurses." On the other hand, this development challenges the nursing profession and expands the demands on service- and emotional labor.

Because all of these factors are interrelated, forming resistance gets complicated. Work intensification is in part an outcome of ideals put forth from within the nursing profession. It is also important to note that NPM implementation on the shopfloor is controlled, maintained, and developed by nurses in management positions. New career paths for nurses open up for increased internal differentiation of the nursing collective, which also contributes to complicating the formation of resistance strategies. It is in this context of both continuity: in the misrecognition of care work and the insistence on women's caring responsibilities, and change: in new developments, strategies, and divisions within the nursing profession, that labor speed-ups and worker adaptation among ward nurses in the public sector should be understood. 
This article has illustrated that because of an NPM restructuring project, nurses at a surgical ward in a Swedish hospital experienced growing workloads over the course of a decade. Work was intensified, both in terms of physical and in terms of emotional efforts. Increased demands on emotional labor were coupled with the restriction of creative altruism. I argue here that in accordance with previous qualitative research, nurses take it upon themselves to resolve conflicts of rationalities and standards of care and efficiency demands in times of neoliberal hegemony. Ackroyd and Bolton (1999, p. 384) have argued that nurses are caught in a crossfire of competing demands of management (to give care to more patients with less resources) and patients (to respond more effectively to their individual needs). This means that "huge demands are placed on the nurses' capacity to deliver the quality of care that their own professional training and professional practice suggest is necessary" (ibid.). These demands are contradictory, but they are contingent on nurses seizing the responsibility to deliver safe and quality care. Wile nurses reproduce the notion of a calling by coping and making due, the "levels of commitment that nurses traditionally exhibit do have practical and emotional limits," as Ackroyd and Bolton (ibid.) point out. The ward I studied struggled with high turnover rates especially among younger nurses, and the older generation of nurses feared making fateful mistakes.

The current neoliberal hegemony asserts that better results can be achieved without additional resources, and that equivalent outcomes can be reached with fewer resources (Hasselbladh et al. 2008, p. 55). But as Cohen (2011, p. 189) has pointed out, "realizing 'efficiency savings' [in healthcare] is comparatively difficult and unlikely to occur without degradation in the treatment accorded to both workers and the bodies they work upon." In this article, I have illustrated that efficiency savings can be implemented and maintained without degradation of frontline services to a certain degree because nurses, responding to women's traditional caring responsibilities that historically have been and continue to be conflated with professional commitments, cover for the organization. It can be concluded, however, that resource depletion is contingent on increased exploitation and performance control of care workers on the shopfloor and their ability and willingness to sacrifice their own time and health for the sake of their patients. This situation is associated with risk-not only in terms of risks associated with the mental and physical well-being of the employees but also in terms of risks associated with their ability of delivering safe-care.

\section{References}

Abbott, A. (1988) The System of Professions: An Essay on the Division of Expert Labor. Chicago: University of Chicago Press.

Acker, J. (1990) 'Hierarchies, Jobs, Bodies: A Theory of Gendered Organizations', Gender \& Society 4(2): 139-158.

Acker, J. (2006) Class Questions. Feminist Answers. Lanham: Rowman \& Littlefield

Ackroyd, S. \& S. Bolton (1999) 'It is Not Taylorism: Mechanisms of Work Intensification in the Provision of Gynaecological Services in a NHS Hospital', Work, Employment \& Society 13(2): 369-387.

Agevall, L. \& K. Jonnergård (2010) 'Vad är professioner?' ['What are Professions?'] in Klasson, T. (ed.) Professioner i offentlig förvaltning [Professions in the Public Sector]. Lund: Studentlitteratur. 
Aili, C. \& L.-E. Nilsson (2007) 'Tensions-Let the Doctor Give an Example’ in Aili, C., L.-E. Nilsson, L. G. Svensson \& P. Denicolo (eds.) In Tension between Organization and Profession: Professionals in Nordic Public Service. Lund: Nordic Academic Press.

Anell, A. (2012) 'Hälso- och sjukvårdstjänster i privat regi' ['Health- and Care Services in Private Management'] in Hartman, L. (ed.) Konkurrensens konsekvenser: vad händer med svensk välfärd? [Consequences of Competition: What is happening in Swedish Welfare?] Stockholm: SNS.

Astvik, W. (2003) Relationer som arbete: förutsättningar för omsorgsfulla möten i hemtjänsten [Relations as work: preconditions for caring interactions in home care work]. Stockholm: Arbetslivsinstitutet.

Barry, K. M. (2007) Femininity in Flight. A History of Flight Attendants. Durham: Duke University Press.

Batnitzky, A. \& L. McDowell (2011) 'Migration, nursing, institutional discrimination and emotional/affective labour: ethnicity and labour stratification in the UK National Health Service', Social \& Cultural Geography 12(2): 181-201.

Bejerot, E. \& A. Astwik (2009) 'När patienten blir kund: nya stressorer och strategier i läkarens arbete' ['When the patient becomes customer: new stressors and strategies in physicians' work'] Växjö University: Work Life in Transition Report No. 2009: 2.

Bejerot, E., G. Aronsson, H. Hasselbladh \& S. Bejerot (2011) 'Läkarkåren en profession med allt mindre stöd och inflytande' ['Doctors-A Profession Facing Less Support and Declining Authority] Läkartidningen 50(108): 2652-2656.

Berg Jansson, A. (2010) I mötet mellan modern management och professionell praktik: Ny organisering möter sjuksköterskeprofessionen [The Meeting between Modern Management and Professional Practice: The Nursing Profession Encounters New Organizing]. Luleå: Luleå Tekniska Universitet, Institutionen för Arbetsvetenskap.

Bessant, J. (1992) “"Good Women and Good Nurses”: Conflicting Identities in the Victorian Nurses Strike, 1985-86', Labour History 63: 155-173.

Blomgren, M. (1999) Pengarna eller livet? Sjukvairdande professioner och yrkesgrupper $i$ mötet med en ny ekonomistyrning [Money or Life? Professions and Occupational Groups in Swedish Health Care Encounter New Management Accounting Models]. Uppsala: Uppsala University Department of Business Studies.

Blomgren, M. (2003) 'Ordering a Profession: Swedish Nurses Encounter New Public Management Reforms', Financial Accountability \& Management 19(1): 45-71.

Blomgren, M. \& I. Sahlin (2007) 'Quests for Transparency: Sings of a New Institutional Era in the Health Care Field' in Christensen, T. \& P. Laegreid (eds.) Transcending New Public Management: The Transformation of Public Sector Reforms. Hampshire: Ashgate.

Bohm, E. (1961) Okänd, godkänd, legitimerad. Svensk Sjuksköterskeförenings första 50 àr. [Unknown, accredited, licensed. Swedish Nursing Association's first fifty years] Stockholm: Svensk Sjuksköterskeförenings förlag.

Bolton, S. C. (2000) 'Who Cares? Offering Emotion work as a "Gift" in the Nursing Labour Process', Journal of Advanced Nursing 32(3): 580-586.

Brah, A. \& A. Phoenix (2004) 'Aint I A Woman? Revisiting Intersectionality', Journal of International Women's Studies, 5(3): 75-86.

Brush, L. D. (2000) 'Gender, Work, Who Cares?! Production, Reproduction, Deindustrialization, and Business as Usual' in Ferree, M. M., J. Lorber \& B. B. Hess (eds.) Revisioning Gender. Walnut Creek: AltaMira Press.

Burawoy, M. (1979) Manufacturing Consent. Changes in the Labor Process Under Monopoly Capitalism. Chicago: University of Chicago Press.

Burawoy, M. (1991) ‘The Extended Case Method' in Burawoy, M., A. Burton, A. A. Ferguson, K. J. Fox, J. Gamson, N. Gartrell, L. Hurst, C. Kurzman, L. Salzinger, J. Schiffman, S. Ui (eds.) Ethnography Unbound: Power and Resistance in the Modern Metropolis. Berkeley, CA: University of California Press. 
Burchell, B. (2002) 'The Prevalence and Redistribution of Job Insecurity and Work Intensification', in Burchell, B., D. Ladipo \& F. Wilkinson (eds.) Job Insecurity and Work Intensification. London: Routledge.

Campbell, M. L. (2006) 'Institutional Ethnography and Experience as Data' in Smith, D. E. (ed.) Institutional Ethnography as Practice. Lanham: Rowman \& Littlefield.

Caspersen, J. (2007) 'Aspects of Professionalism: Collective Nursing-Personalised Teaching?' in Aili, C., L. Nilsson, L. G. Svensson \& P. Denicolo (eds) In Tension between Organization and Profession. Lund: Nordic Academic Press.

Chiarella, M. (2002) The Legal and Professional Status of Nursing. Edinburgh: Churchill Livingstone.

Christensen, T. \& P. Laegreid (2007) 'Introduction-Theoretical Approach and Research Questions' in Christensen, T. \& P. Laegreid (eds.) Transcending New Public Management: The Transformation of Public Sector Reforms. Hampshire: Ashgate.

Clarke, J. (2004) Changing Welfare, Changing States: New Directions in Social Policy. London: Sage.

Cohen, R. L. (2011) 'Time, Space, and Touch at Work: Body Work and Labor Process (Re) organization', Sociology of Health \& Illness 33(2): 189-205.

Cooke, H. (2006) 'Seagull Management and the Control of Nursing Work', Work, Employment \& Society 20(2): 222-243.

Connell, R. W. (1987) Gender and Power. Cambridge: Polity Press.

Czarniawska, B. (2011) 'How to Study Gender Inequality in Organizations?' in Jeans, E. L., D. Knights \& P. Y. Martin (eds.) Handbook of Gender, Work, and Organization. London: Wiley.

Dahle, R. (2005) 'Men, Bodies, and Nursing' in Morgan, D., B. Bradth \& E. Kvande (eds.) Gender, Bodies, and Work. London: Ashgate.

Davies, C. (1995) Gender and the Professional Predicament in Nursing. Buckingham: Open University Press.

Davies, A. \& R. Thomas (2000) 'Researching Public Sector Change: The Argument for a Gender-Inclusive Framework', Public Management 2(4): 547-554.

DeVault, M. \& L. McCoy (2006) 'Institutional Ethnography: Using Interviews to Investigate Ruling Relations' in Smith, D. E. (ed.) Institutional Ethnography as Practice. Lanham: Rowman \& Littlefield.

Du Gay, P. \& G. Salaman (1992) 'The Cult(ure) of the Customer', Journal of Management Studies 29(5): 615-633.

Ehrenreich, B. (2009) Bright-sided: How the Relentless Promotion of Positive Thinking Has Undermined America. New York, NY: Metropolitan Books.

Eliasson, M. (2011) 'Assistant and auxiliary nurses in crisis times', Stockholm: Institute for Labour Market Policy Evaluation, Woring paper 2011: 1.

England, P. \& N. Folbre (1999) 'The Cost of Caring', Annals of the American Academy of Political and Social Science 561: 39-51.

England, P., M. Budig \& N. Folbre (2002) 'Wages of Virtue: The Relative Pay of Care Work', Social Problems 49: 455-473.

Erlöv, I. \& K. Petersson (1992) Från kall till personlighet: sjuksköterskans utbildning och arbete under ett sekel [From a calling to humanistic healing? A century of nurses' training work]. Lund: Pedagogiska institutionen, Lunds universitet.

Falkenberg, H. (2010) How Privatization and Corporatization Affect Healthcare Employee's Work Climate, Work Attitudes and Ill-health: Implications of Social Status. Stockholm: Stockholm University.

Ferlie, E., L. Ashburner, L. Fitzgerald \& A. Pettigrew (1996) The New Public Management in Action. Oxford: Oxford University Press.

Fleming, P. \& A. Spencer (2003) 'Working at a Cynical Distance', Organization 10(1): 157-179. 
Foote Whyte, W. (1948) Human Relations in the Restaurant Industry. New York, NY: McGraw-Hill.

Foster, D. \& Hoggett, P. (1999) 'Changes in the Benefits Agency: Empowering the Exhausted Worker', Work, Employment and Society 13(1): 9-39.

Franssén, A. (1997) Omsorg $i$ tanke och handling: en studie av kvinnors arbete $i$ vården [Caring in mind and action: a study of women's care work], Lund: Arkiv.

Gardulf, A., M. Orton, L. Eriksson, M. Undén, B. Arnetz, K. Nilsson Kajermo \& G. Nordström (2008) 'Factors of Importance for Work Satisfaction among Nurses in a University Hospital in Sweden', Scandinavian Journal of Caring Science 22: 151-160.

Glasberg, A., A. Norberg \& A. Söderberg (2007) 'Sources of Burnout among Healthcare Employees as Perceived by Managers', Journal of Advanced Nursing 60(1): 10-19.

Goffman, E. (1959) The Presentation of Self in Everyday Life, London: Penguin.

Green, F. (2001) 'It's Been a Hard Day's Night: The Concentration and Intensification of Work in Late Twentieth-Century Britain', British Journal of Industrial Relations 39: 53-80.

Gustafsson, R. Å. (2000) Välfärdstjänstearbetet: Dragkampen mellan offentligt och privat $i$ ett historie-sociologiskt perspektiv [Welfare Service Work: The Tension between Public and Private from a Historical Sociological Perspective]. Göteborg: Daidalos.

Gustafsson, G. (2009) Att bli eller inte bli utbränd: ett komplext fenomen bland vardpersonal på samma arbetsplatser [To Burn Out or Not Burn Out: A Complex Phenomenon among Care Workers in the Same Workplaces]. Umeå: Department of Nursing.

Hasselbladh, H., E. Bejerot \& R. Å. Gustafsson (2008) Bortom New Public Management: Institutionell transformation i svensk sjukvård [Beyond New Public Management: Institutional Transformation in Swedish Healthcare]. Lund: Academia Adacta.

Hasselhorn, H., P. Tackenberg \& B. H. Müller (2003) 'Working conditions and intent to leave the profession among nursing staff in Europe', SALTSA Report No 7: 2003.

Hertting, A., K. Nilsson, T. Theorell \& U. Sätterlund Larsson (2005) 'Assistant Nurses in the Swedish Healthcare Sector during the 1990s: A Hard-Hit Occupational Group with a Tough Job', Scandinavian Journal of Public Health 33: 107-113.

Hochschild, A. R. (1983) The Managed Heart: Commercialization of Human Feeling. Berkeley, CA: University of California Press.

Holm, U. (1995) Det räcker inte att vara snäll. Om empati och professionellt bemötande i människovardande yrken [Being nice is not enough. On empathy and professional behavior in care professions]. Stockholm: Natur \& Kultur.

James, N. (1992) 'Care = Organisation + Physical Labour + Emotional Labour', Sociology of Health \& Illness 14(4): 489-509.

Jewkes, R., N. Abrahams \& Z. Mvo (1998) 'Why Do Nurses Abuse Patients? Reflections from South African Obstetric Services', Social Science and Medicine 47(11): 1781-1795.

Kirpal, S. (2004) 'Work Identities of Nurses: Between Caring and Efficiency Demands', Career Development International 9: 274-304.

Lindgren, G. (1992) Doktorer, systrar och flickor: om informell makt [Doctors, Sisters, and Girls: On Informal Power]. Stockholm: Carlssons.

Lindqvist, L. \& L. Aidemarn (2005) Sjukhus som bolag: om legitimitet och identitet [Hospitals as Corporations: On Legitimacy and Identity]. Stockholm: SNS Förlag.

Läkartidningen (2008) 'Landstingen satsar på att förebygga postoperativa sårinfektioner' ['The Counties Work to Prevent Postoperative Wound Infections'], 1-2(105): 47-48.

Mackay, L. (1989) Nursing a Problem. Milton Keynes: Open University Press.

McDowell, L. (2009) Working Bodies. Interactive Service Employment and Workplace Identities. London: Wiley-Blackwell.

Meier, K. J., S. H. Mastracci \& K. Wilson (2006) 'Gender and Emotional Labor in Public Organizations: An Empirical Examination of the Link to Performance', Public Administration Review 66(6): 899-909. 
Montin, S. (2012) 'Politik och förvaltning i förändring: en forskningsbaserad översikt' ['Politics and governance in transition: a research-based overview'], Stockholm: SKL Rapportserie, available at http://www.skl.se/vi_arbetar_med/demos/demokratiutveckling/ uppdrag-och-samspel-mellan-ledande-politiker-och-tjansteman/politik-och-forvaltningi-forandring.

Morris, J. A. \& D. C. Feldman (1996) 'The Dimensions, Antecedents, and Consequences of Emotional Labor', Academy of Management Review 21(4): 986-1010.

Mulinari, D. (2010) 'Postcolonial Encounters: Migrant Women and Swedish Midwives' in Fink, J. \& A. Lundqvist (eds.) Changing Relations of Welfare: Family, Gender and Migration in Britain and Scandinavia. Farnham: Ashgate.

Nelson, J. (1996) Feminism, Objectivity and Economics. London: Routledge.

Nordgren, L. (2007) Från patient till kund: intåget av marknadstänkande i sjukvården och förskjutningen av patientens position [From Patient to Customer: The Arrival of Market Ideas in Healthcare and the Displacement of the Position of the Patient] Lund: Lund Business Press.

Nylinder, P. (2011) 'Perceptions of Budgetary Control: A Study of Differences Across Managers in Swedish Public Primary Healthcare Related to Professional Background and Sex', Journal of Nursing Management 19: 664-672.

Ong, A. (1987) Spirits of Resistance and Capitalist Discipline. Factory Women in Malaysia. New York, NY: State University of New York Press.

Porter, S. (1993) 'Critical Realist Ethnography: The Case of Racism and Professionalism in a Medical Setting', Sociology 27(4): 591-609.

Radwin, L. E. \& K. Alster (2002) 'Individualized Nursing Care: An Empirically Generated Definition', International Nursing Review 49(1): 54-63.

Roberts, D. (1997) 'Spiritual and Menial Housework', Yale Journal of Law and Feminism 9(51): 51-80.

Robertsson, E., M. Malmström \& S E. Johansson (2005) 'Do Foreign-Born Women in Sweden Have an Increased Risk of Nonnormal Childbirth?', Acta Obstetricia et Gynecologica Scandinavia 84(9): 825-832.

Rowe, M. M. \& H. Sherlock (2005) 'Stress and Verbal Abuse in Nursing: Do Burned Out Nurses Eat Their Young?', Journal of Nursing Management 13: 242-248.

Salzinger, L. (2000) 'Manufacturing Sexual Objects: "Harassment”, Desire and Discipline on a Maquiladora Shopfloor, Ethnography 1(1): 67-92.

Selberg, R. (2012) Femininity at Work: Gender, Labour and Changing Relations of Power in a Swedish Hospital. Lund: Arkiv.

Skeggs, B. (1997) Formations of Class and Gender: Becoming Respectable. London: Sage.

Smith, D. E. (2005) Institutional Ethnography-A Sociology for People. Lanham: Rowman \& Littlefied.

Stockholm County (1999) 'Vårdens arbetshälsorapport: Vårdarbetets villkor och konsekvenser för arbetshälsan' ['Report on working conditions in healthcare: Conditions and consequences of care work on work health']. Stockholm: Stockholm County Public Health, available at http://www.folkhalsoguiden.se/Rapport.aspx?id=926.

SWEA (2012) 'Nationell tillsyn av överbeläggningar inom akutsjukvården' ['National Oversight of Patient Over-Influx in Emergency Medicine'], Report 2012: 2.

Theodosius, C. (2008) Emotional Labour in Health Care: The Unmanaged Heart of Nursing. London: Routledge.

Twigg, J. (2000) 'Care Work as a Form of Body Work', Ageing and Society 20: 389-411.

Twigg, J., C. Wolkowitz, R. L. Cohen \& S. Nettleton (2011) ‘Conceptualizing Body Work in Health and Social Care', Sociology of Health \& Illness 33(2): 171-188.

Van Thiel, S. \& F. L. Leeuw (2002) 'The Performance Paradox in the Public Sector', Public Performance \& Management Review 25(3): 267-281. 
Waerness, K. (1984) 'The Rationality of Caring', Economic and Industrial Democracy 5(1984): 185-211.

Wald, H. L., A. M. Epstein, T. A. Radcliffe \& A. M. Kramer (2008) 'Extended Use of Urinary Catheters in Older Surgical Patients: A Patient Safety Problem?', Infection Control and Hospital Epidemiology 29(2): 116-124.

Whitehead, M., R. A.. Gustafsson \& F. Diderichsen (1997) 'Why is Sweden Rethinking Its NHS Style Reforms?', British Medical Journal 315: 935-946.

Widerberg, K. (2005) 'Embodied Gender Talks-The Gendered Discourse of Tiredness', in Morgan, D., B. Bradth \& E. Kvande (eds.) Gender, Bodies and Work. London: Ashgate.

Wilkins, K. (2007) 'Work Stress Among Health Care Providers', Health Reports (Statistics Canada, Catalogue 82-003) 18(4): 32-36.

Williams, C. (2006) Inside Toyland: Working, Shopping and Social Inequality, Berkeley, CA: University of California Press.

Willis, E. (2005) 'The Variable Impact of New Public Management and Budget Cuts on the Work Intensification of Nurses and Doctors in one Public Hospital in South Australia Between 1994 and 2000', The Australian Bulletin of Labor 31(3): 255-269.

Wolkowitz, C. (2006) Bodies at Work. London: Sage.

Zeytinoglu, I. U., M. Denton, S. Davies, A. Baumann, J. Blythe \& L. Boos (2007) 'Associations between Work Intensification, Stress and Job Satisfaction: The Case of Nurses in Ontario', Industrial Relations 62(2): 201-225.

\section{Other sources}

About.com/Surgery, available at http://surgery.about.com/od/questionsanswers/qt/What-IsA-Foley-Catheter.htm (Aug 22, 2012).

\section{End notes}

${ }^{1}$ I am not trained as a nurse, nor have I ever worked professionally in any care settings. Although I did participate to a limited degree in some tasks, such as fetching drinks for patients, help make beds, etc., I conceptualize this as nonparticipatory observation. I compare my highly limited participation in the work with research based on participatory observations in which the researcher has been employed as a nurse or an aid, such as Porter (1993) or Franssén (1997). 